\title{
Daily growth increments in the otoliths of European smelt Osmerus eperlanus larvae
}

\author{
Aquiles Sepúlveda \\ Institut für Hydrobiologie und Fischereiwissenschait, Universität Hamburg, Olberweg 24, D-22767 Hamburg, Germany
}

\begin{abstract}
Fish larvae of European smelt. Osmerus eperlanus L. were collected in the lower Elbe River, Germany, and aged using daily growth increments in the otoliths The otolith microstructure in the sagittae of larvae caught within a $24 \mathrm{~h}$ period was examined and the daily pattern in increment formation was validated using the marginal increment technique. Smelt larvae were also caught at a fixed station between April and May 1993. The formation of the first daily growth increment corresponds to the onset of exogenous feeding. The width of growth increments, radii, perimeters and areas of the otoliths were measured using an image analysis system. A power function was fitted between otolith radius and standard length. Integrated somatic growth rate was estimated as $0.556 \mathrm{~mm} \mathrm{~d}^{-1}$ from the linear relationship between standard length and the number of daily growth increments enumerated from the sagittae. Otolith growth was best described using a 1-cycle Gompertz function. Backcalculated hatching dates showed 2 main hatching batches during April 1993 and the time span of the hatching was not longer than $16 \mathrm{~d}$. There were no significant differences among back-calculated otolith growths of 3 different hatching groups. At oxygen concentrations of $<4.5 \mathrm{mg} \mathrm{l}^{-1}$, recent otolith growth showed high variability and negative values.
\end{abstract}

KEY WORDS: Fish larvae Otolith Age determination Daily growth Hatching dates Elbe estuary

\section{INTRODUCTION}

European smelt Osmerus eperlanus L. is the most abundant fish species in the lower Elbe River, Germany (Möller 1988, Thiel et al. 1994). The anadromous smelt has a relatively high fecundity and spawns in the lower Elbe, upstream and downstream of the city of Hamburg, Germany, mainly along southern shores and within tributaries. The early life history of the Elbe smelt has been described by Ehrenbaum (1894) and Lillelund (1961). The egg, which has a diameter ranging from 0.75 to $0.90 \mathrm{~mm}$, is spawned between March and April, depending on the water temperature. The fish hatch as larvae at approximately $4.8 \mathrm{~mm}$ total length after $17 \mathrm{~d}$ at $12^{\circ} \mathrm{C}$ (Borchardt 1986). The yolk sac is fully absorbed at a total length of $8 \mathrm{~mm}, 9 \mathrm{~d}$ after hatching at $17.7^{\circ} \mathrm{C}$ (Lillelund 1961). Yolk-sac larvae are transported from the spawning grounds to the head of the estuary, and afterwards develop in the marginal areas of the river (Sepúlveda et al. 1993). In May, high numbers of smelt larvae can be found in marginal areas immediately downstream of Hamburg.
Environmental factors may determine the recruitment and larval growth of smelt in the Elbe estuary. Oxygen depletion occurs in the retention areas and probably causes high mortalities of smelt larvae. An early onset of oxygen depletion can lead to an extinction of fishes in the estuary (Moller \& Scholz 1991). Since 1990 the extent and frequency of this phenomenon has diminished, probably due to reduced pollution (Reincke et al. 1992). The effects of different environmental factors, e.g. temperature, $\mathrm{pH}$, food availability and oxygen concentrations, on otolith growth and fish growth are pointed out by different authors (Brothers \& McFarland 1981, Karakiri \& von Westernhagen 1989). Otoliths are a powerful tool to recognize transitions and growth patterns (Campana 1992), and may provide insight into the recruitment mechanisms of smelt.

Age determination through otolith microstructures can give the age of fish larvae, hatching date distributions and estimates of daily growth rate (Moksness 1992). However, this kind of analysis requires the validation of temporal patterns of deposition of the increments. Validation techniques include monitoring reared 
larvae of known age (Rice et al. 1987, Moksness 1992), marking otoliths with tetracycline or other fluorescent compounds (Tsukamoto et al. 1989), observing early life history features that can offer a statistical inference in the counting of increments (Karakiri et al. 1991), or marginal increment analysis (Ré 1984, Ré \& Gonçalves 1993).

Timola (1977) showed the growth pattern in otoliths of Bothnian smelt using scanning electron microscopy and described the fast growth zones (summer ring) consisting of approximately 170 growth increments. Lardeaux (1986a) also recognized microstructures in the sagittae of smelt from the Loire River, France. Garnås (1982) performed investigations on the determination of age and growth comparisons for different year classes of mature smelts (age $1+$ to $6+$ ).

The main purpose of the present study was to investigate the growth pattern of early life stages of European smelt in the lower Elbe River. The formation of growth increments and their daily nature were verified. Estimates were made of specific growth rate in the nursery and in the maximal retention zone of smelt larvae.

\section{MATERIAL AND METHODS}

European smelt larvae were caught from 21 April to 17 May 1993, every $2 \mathrm{~d}$ at a fixed station (Stn 1, 53 $32^{\prime}$ $50^{\prime \prime} \mathrm{N}, 9^{\circ} 51^{\prime} 21^{\prime \prime} \mathrm{E}$ ), located in the upper part of the es- tuary (Fig. 1). Fish larvae were also collected during a 24 h period at $\operatorname{Stn} 2\left(53^{\circ} 32^{\prime} 42^{\prime \prime}\right.$ N, $\left.9^{\circ} 48^{\prime} 10^{\prime \prime} \mathrm{E}\right)$ and $\operatorname{Stn} 3$ $\left(53^{\circ} 33^{\prime} 20^{\prime \prime} \mathrm{N}, 9^{\circ} 41^{\prime} 50^{\prime \prime} \mathrm{E}\right.$; Fig. 1). The mean depths at these stations are $2.90,2.44$ and $3.91 \mathrm{~m}$, respectively. Surface water temperature and salinity were estimated using a portable conductivity meter [LF 196, Wissenschaftlich-Technische Werkstätten (WTW)]. Dissolved oxygen was taken using a portable oxymeter (OXI 196. WTW). Maximum and minimum daily oxygen concentrations were obtained from the hydrological station at Blankenese (Fig. 1, ARGE ELBE unpubl. data).

Plankton samples were taken with the RV 'Ratibor' using 2 different framed ring trawls with mesh size of $300 \mu \mathrm{m}$ (0.5 m diameter) and $1000 \mu \mathrm{m}$ ( $0.9 \mathrm{~m}$ diameter), both provided with digital flowmeters (General Oceanics). At each site, the gear was positioned against the current; however alternative oblique hauls, moving in a circle, were performed with an outboard motor boat when the stream velocities were lower than $0.3 \mathrm{~m} \mathrm{~s}^{-1}$. The duration of the hauls was on the average $1.45 \mathrm{~min}$. A total of 39 samples were taken for otolith microstructure analysis. All samples were fixed immediately after collection in $5 \%$ formaldehyde solution in filtered water buffered with sodium borate ( $\mathrm{pH} 8.5$ to 9 ).

Smelt larvae were sorted and counted in the laboratory. Larval standard length was measured to the nearest $0.01 \mathrm{~mm}$ using an electronic drawing board attached to a stereomicroscope equipped with a drawing mirror. Each pair of sagittae and some lapilli were dissected out using fine needles, washed with distilled
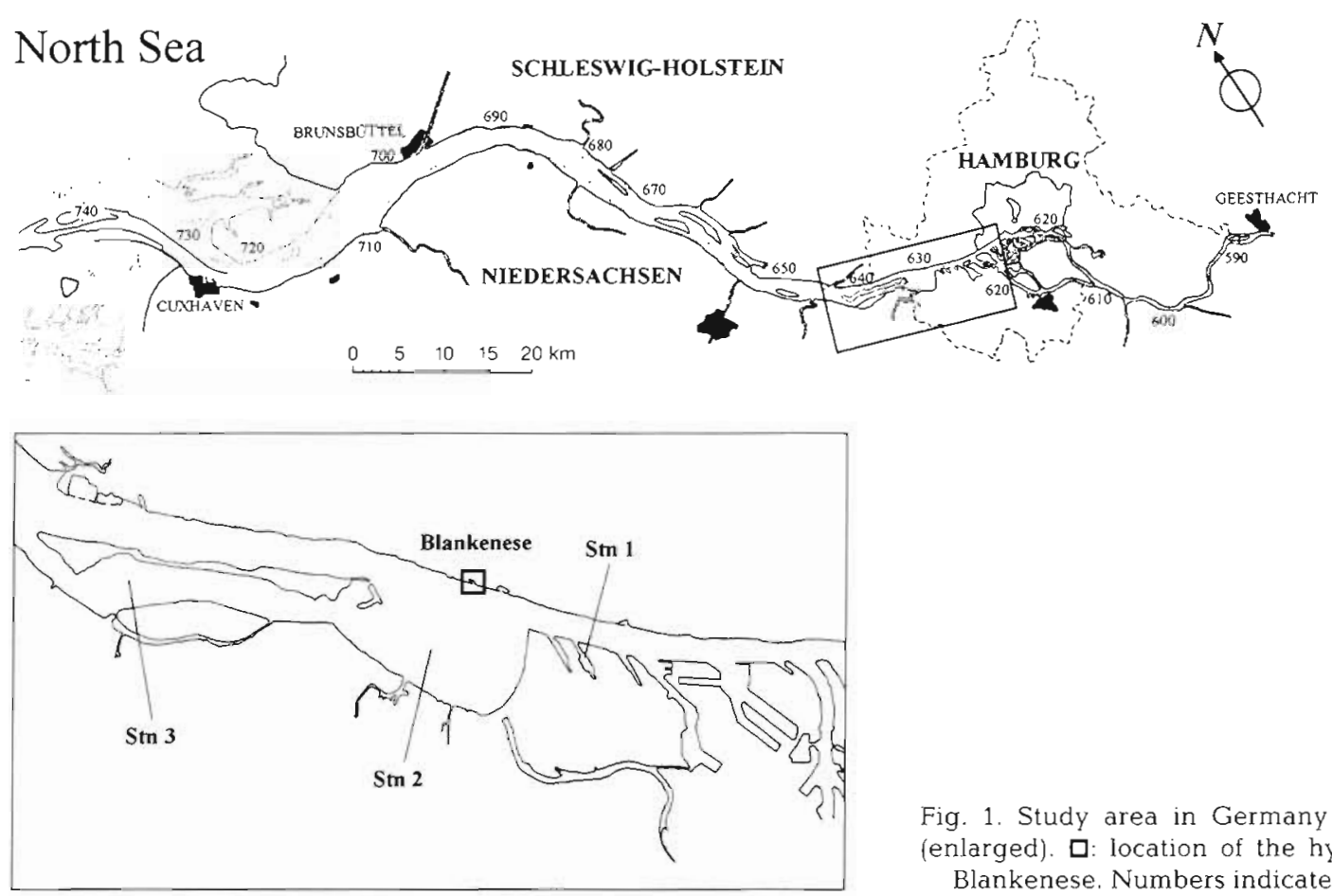

Fig. 1. Study area in Germany with sampling sites (enlarged). $\square$ : location of the hydrological station at Blankenese. Numbers indicate stream kilometers 
water and $95 \%$ alcohol, and mounted using the mounting media DePeX (Serva) to analyze otolith microstructures. The method used for dissecting, mounting and observing the otoliths was described earlier by Ré (1983). The otoliths were mounted with their plane face (internal face) downwards. Otolith measurements were performed using an image analysis system based on a CCD video camera fitted to a compound optical microscope and connected to a multiscan monitor obtaining a maximal magnification of $3700 \times$. The video camera was attached to a digitizer board (PC Vision VS-100-AT, Imaging Technology, Inc.) installed in a personal computer. Otolith images obtained with this system were analyzed with image analysis software (OPTIMAS v. 4.0, BioScan). Four measurements were taken: otolith radius $(\mu \mathrm{m})$, perimeter $(\mu \mathrm{m})$ and area $\left(\mu \mathrm{m}^{2}\right)$, and widths of individual growth increments $(\mu \mathrm{m})$. Radii were measured from the central focus to the postrostrum in the sagittae. Area and perimeter measurements were obtained by means of an autotracing function around the otoliths.

To verify the daily nature in the formation of the otolith growth increments, the marginal increment technique was applied. This technique consists of catching fish larvae hourly over a $24 \mathrm{~h}$ period. The time to completion of the increment on the edge of the otolith can be determined by following the its width in relation to that of immediately preceding increment. The percentage of marginal increment completion ( $C$ ), can be estimated as (Tanaka et al. 1981, Ré 1984):

$$
C=100 \frac{W_{n}}{W_{n-1}}
$$

where $W_{n}$ represents the width of the increment in the process of formation and $W_{n-1}$ the width of the last formed increment.

To determine the integrated growth rate, the linear relationship between daily growth increments and standard length was regressed. Length-frequency analysis and the length-weight relationship established for smelt larvae facilitate the estimation of the daily length increment (DLI) and the specific growth rate (SGR), respectively. The length $(L)$ to wet weight $(W)$ relationship for 265 fresh smelt larvae was estimated to be $W=7.683 \times 10^{-7} L^{3476}, \mathrm{R}^{2}=0.993$.

SGR expressed as a percentage was calculated according to the following formula (Houde \& Scheckter 1981):

$$
\operatorname{SGR}=\left(\exp \frac{\ln W_{t_{2}}-\ln W_{t_{1}}}{t_{2}-t_{1}}-1\right) \times 100
$$

where SGR is in percentage per day and $W_{t_{1}}$ and $W_{t_{2}}$ are, in this study, average wet weights (mg) of larvae at days $t_{1}$ and $t_{2}$
DLI ( $\left.\mathrm{mm} \mathrm{d} \mathrm{d}^{-1}\right)$ was estimated according to:

$$
\mathrm{DLI}=\frac{S L_{2}-S L_{1}}{t_{2}-t_{1}}
$$

where $S L_{1}$ and $S L_{2}$ are the average standard length (in $\mathrm{mm}$ ) of the larvae at days $t_{1}$ and $t_{2}$.

\section{RESULTS}

\section{Validation of daily growth increments}

A total of 219 sagittae were considered for analysis. Otoliths were selected from larvae between 7.84 and $21.60 \mathrm{~mm}$ SL (mean $=16.92 \mathrm{~mm}$ ). However, few otoliths from fish larvae smaller than $9.0 \mathrm{~mm}$ could be analyzed due to difficulties in discerning increments near the otolith margin and the narrow widths in the last increment. Complete deposition of the marginal increment (discontinuous zone) was observed around sunrise (05:45 and 08:45 h, local time) with the incremental zones being deposited in an oscillatory trend during the rest of the $24 \mathrm{~h}$ cycle (Fig. 2). In 21 cases, the completed increment was up to approximately $5 \%$ wider than the previously formed increment and hence, represented daily growth in the otolith.

\section{Otolith growth and microstructure}

Yolk-sac larvae (SL approximately $<8.0 \mathrm{~mm}$ ) were examined for the occurrence of growth increments, but obvious evidence of deposition of growth zones during the endogenous feeding stage did not exist. Smelt larvae with functional mouth and remaining yolk sac are already capable of performing exogenous feeding.

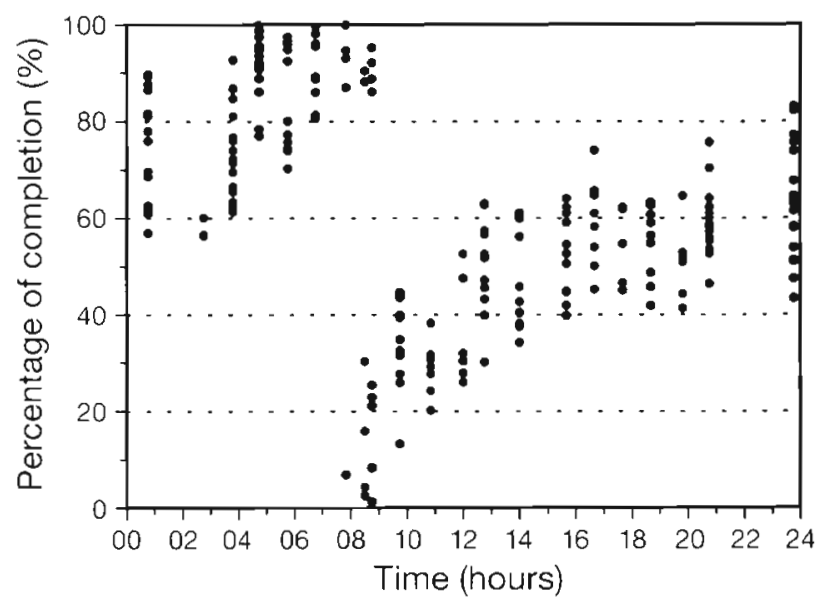

Fig. 2. Osmerus eperlanus. Diel changes in the index of completion (\%) of the marginal increment in the sagittae of smelt larvae (219 otoliths) sampled at Stns 2 and 3 


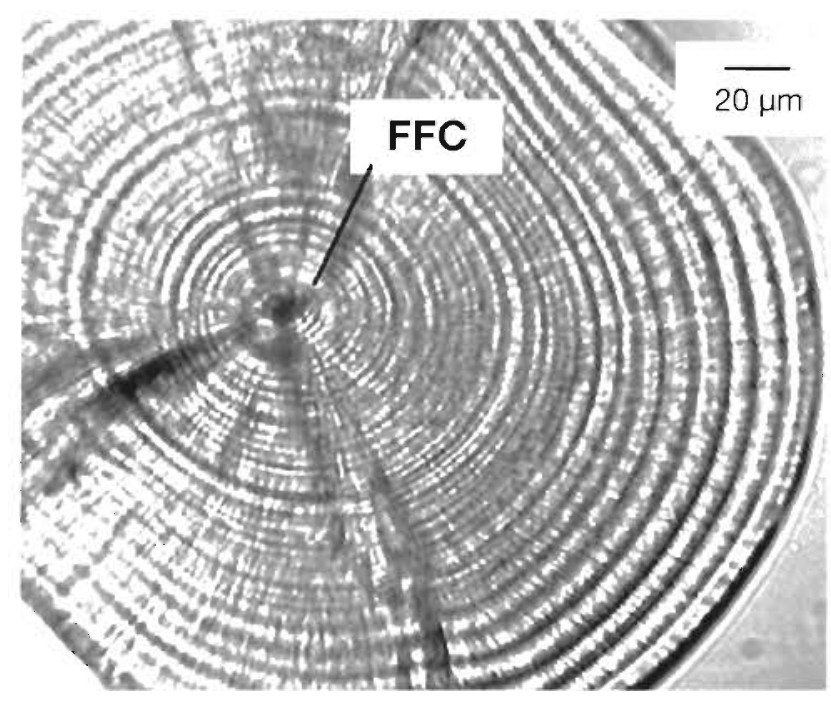

Fig. 3. Osmerus eperlanus. Processed image print of a smelt larval sagitta with a standard length of $19.8 \mathrm{~mm}$. FFC: the first feeding check increment.

It was then assumed that the first discontinuous zone corresponds to the first feeding check. Measurements in 164 sagittae confirmed that the mean radius of the first feeding check was $10.93 \pm 1.22 \mu \mathrm{m}$ (Fig. 3). The mean size of the daily growth increments in the sagittae varied from $2.16 \mu \mathrm{m}$ for the first deposited ring $(\mathrm{n}=162)$ to $11.4 \mathrm{\mu m}$ for the wider increments at the edge of the otoliths ( $n=13$ ); whereas the mean size in the lapilli varied from $1.25 \mu \mathrm{m}$ for the first $(\mathrm{n}=26)$ to $4.11 \mu \mathrm{m}$ for the last $(\mathrm{n}=1)$ daily growth increments.

Statistical comparisons were made between different sagittal otoliths on several different measurements performed with the use of the image analysis system. There were no significant differences between the radius, area and perimeter of both sagittae (Wilcoxon test, $\mathrm{p}>0.05, \mathrm{n}=74$ ). The comparison between the number of increments enumerated in the right and left sagittae and the lapilli showed no significant differences (Wilcoxon test, $\mathrm{p}>0.05, \mathrm{n}=22$ ). However, counting in the lapilli was more laborious due to smaller size and increment width.

The statistical intercept of the linear regression between daily growth increments and standard length (Fig 4) was $6.191 \mathrm{~mm}$ and the integrated growth rate (slope) corresponded to $0.556 \mathrm{~mm} \mathrm{~d}^{-1}\left(\mathrm{R}^{2}=0.912\right.$, $\mathrm{n}=164$ ). Length-frequency distributions are shown in Fig 5. Results of daily length increment (DLI) and the specific growti rate (SGR) estimates are shown in Table 1.

To compare the relationship between different measurements of the sagittae (radius $O R$, area $A R$ and perimeter $\mathrm{PE}$ ) and fish length, power curves were fitted. The parameters of the power regressions are

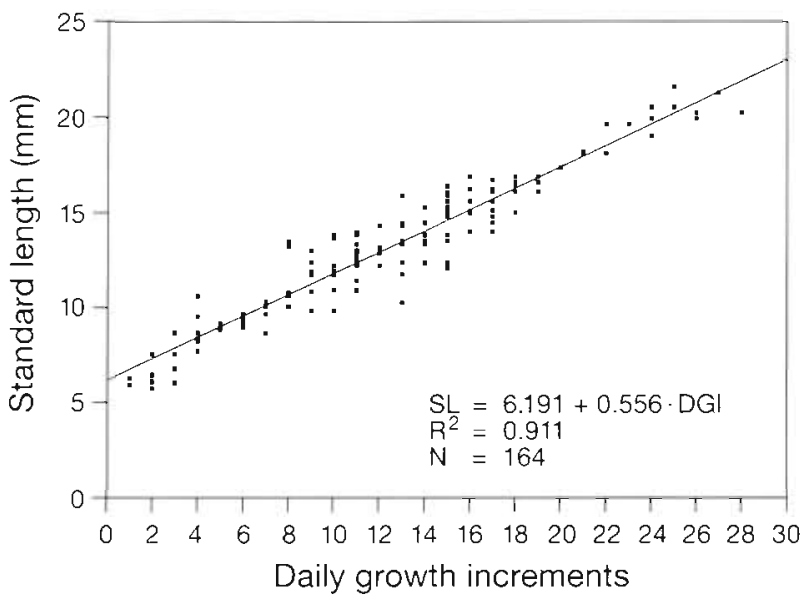

Fig. 4. Osmerus eperlanus. Estimated relationship between the number of daily growth increments (DGI) versus standard length (SL) for larvae of European smelt collected every $2 \mathrm{~d}$ at Stn 1 from 21 April to 17 May 1993

summarized in Fig. 6. All 3 fitted curves are significant $(p<0.001)$. The relationship between standard length and the area of the otolith showed the best fit $\left(\mathrm{R}^{2}=\right.$ $0.942, \mathrm{SE}=0.071$ )

The relationship between the number of daily growth increments and otolith size (i.e. radius, area and perimeter) was evaluated by fitting exponential curves (Fig. 7). In all cases, the curves showed a good fit for counts lower than 22 daily growth increments. Points to the right (i.e. older fish larvae) deviated more from the fitted curve, suggesting a decreasing otolith growth rate

Table 1. Osmerus eperlanus. Summary of the mean length estimates for the smelt larvae between 21 April and 17 May 1993.

DLI: daily length increment; SGR: specific growth rate

\begin{tabular}{|c|c|c|c|c|c|}
\hline Date & & $\begin{array}{l}\text { Mean length } \\
(\mathrm{mm})\end{array}$ & $\begin{array}{l}\text { Mean weight } \\
(\mathrm{mg})\end{array}$ & $\begin{array}{c}\text { DLI } \\
\left(\mathrm{mm} \mathrm{d}^{-1}\right)\end{array}$ & $\begin{array}{c}\text { SGR } \\
\left(\% d^{-1}\right)\end{array}$ \\
\hline \multirow{4}{*}{ April } & 21 & 5.93 & 0.373 & 0.590 & 32.43 \\
\hline & 26 & 8.88 & 1.521 & 0.315 & 12.66 \\
\hline & 28 & 9.51 & 1.930 & 0.359 & 13.48 \\
\hline & 30 & 10.23 & 2.485 & 0.663 & 23.60 \\
\hline \multirow[t]{9}{*}{ May } & 2 & 11.55 & 3.797 & 0.581 & 18.14 \\
\hline & 4 & 12.71 & 5.299 & 0.625 & 17.71 \\
\hline & 6 & 13.96 & 7.342 & 0.356 & 9.04 \\
\hline & 8 & 14.68 & 8.730 & 0.386 & 9.32 \\
\hline & 10 & 15.45 & 10.433 & 0.157 & 3.55 \\
\hline & 12 & 15.74 & 11.188 & 0.679 & 15.43 \\
\hline & 14 & 17.12 & 14.908 & 0.176 & 3.60 \\
\hline & 16 & 17.47 & 16.001 & 0.431 & 8.84 \\
\hline & 17 & 17.91 & 17.415 & & \\
\hline \multicolumn{2}{|l|}{ Mean } & 13.17 & 7.802 & 0.443 & 13.98 \\
\hline \multicolumn{2}{|l|}{$\mathrm{SD}$} & 3.59 & 5.611 & 0.174 & 7.94 \\
\hline
\end{tabular}



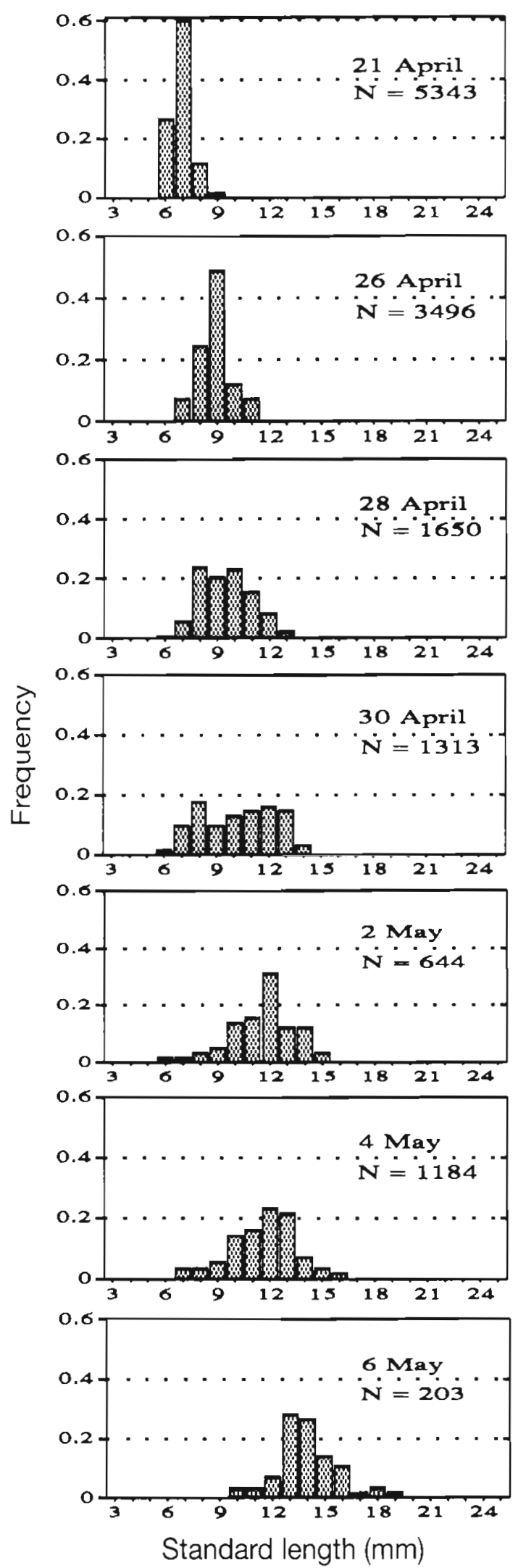
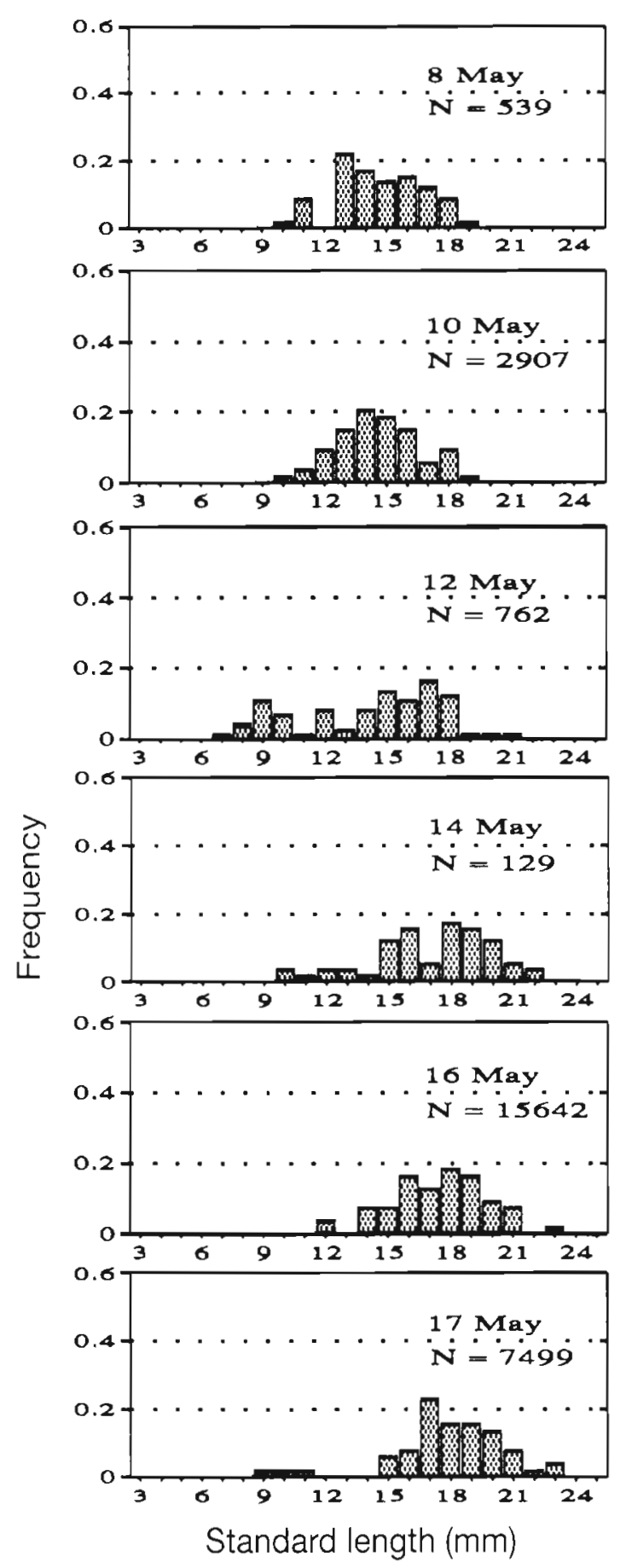

Fig. 5. Osmerus eperlanus. Length-frequency distributions of smelt larvae. N: no. of individuals per $100 \mathrm{~m}^{3}$ 

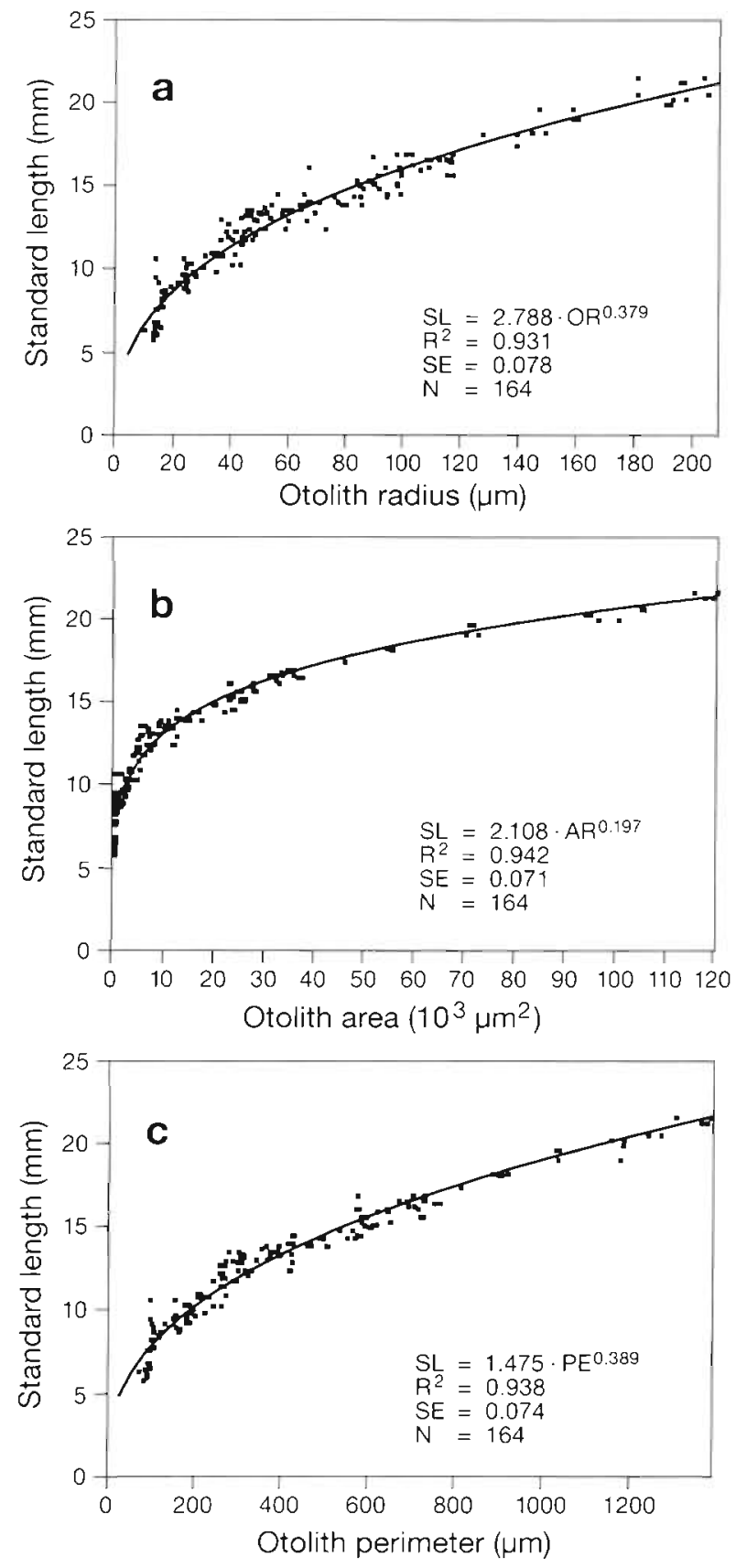

Fig. 6. Osmerus eperlanus. Relationship between different otolith measurements and standard length (SL). Power models for (a) otolith radius (OR) versus $\mathrm{SL}$, (b) otolith area

$(A R)$ versus SL, and (c) otolith perimeter (PE) versus SL

\section{Hatching date distribution}

The average temperature at the sampling stations during the period $21 \mathrm{Apri}$ to 17 May 1993 was $17.8^{\circ} \mathrm{C}$ $\left(\mathrm{SD}=0.59^{\circ} \mathrm{C}, \mathrm{n}=39\right)$. Smelt larvae deposit the first increment on their otoliths near the end of the yolk-sac stage. According to Lillelund's (1961) experimental observations regarding the span of survival of smelt yolk-sac larvae, the posthatching age is estimated by adding $9 \mathrm{~d}$ to the number of increments counted in the otoliths. Back-calculated hatching date distribution for smelt larvae for 1993 is summarized in Fig. 8. The hatching dates showed a bimodal distribution with a first peak centered at about 12 April and a secondary peak on 18 April. Hatching period duration appeared to be approximately $16 \mathrm{~d}$.
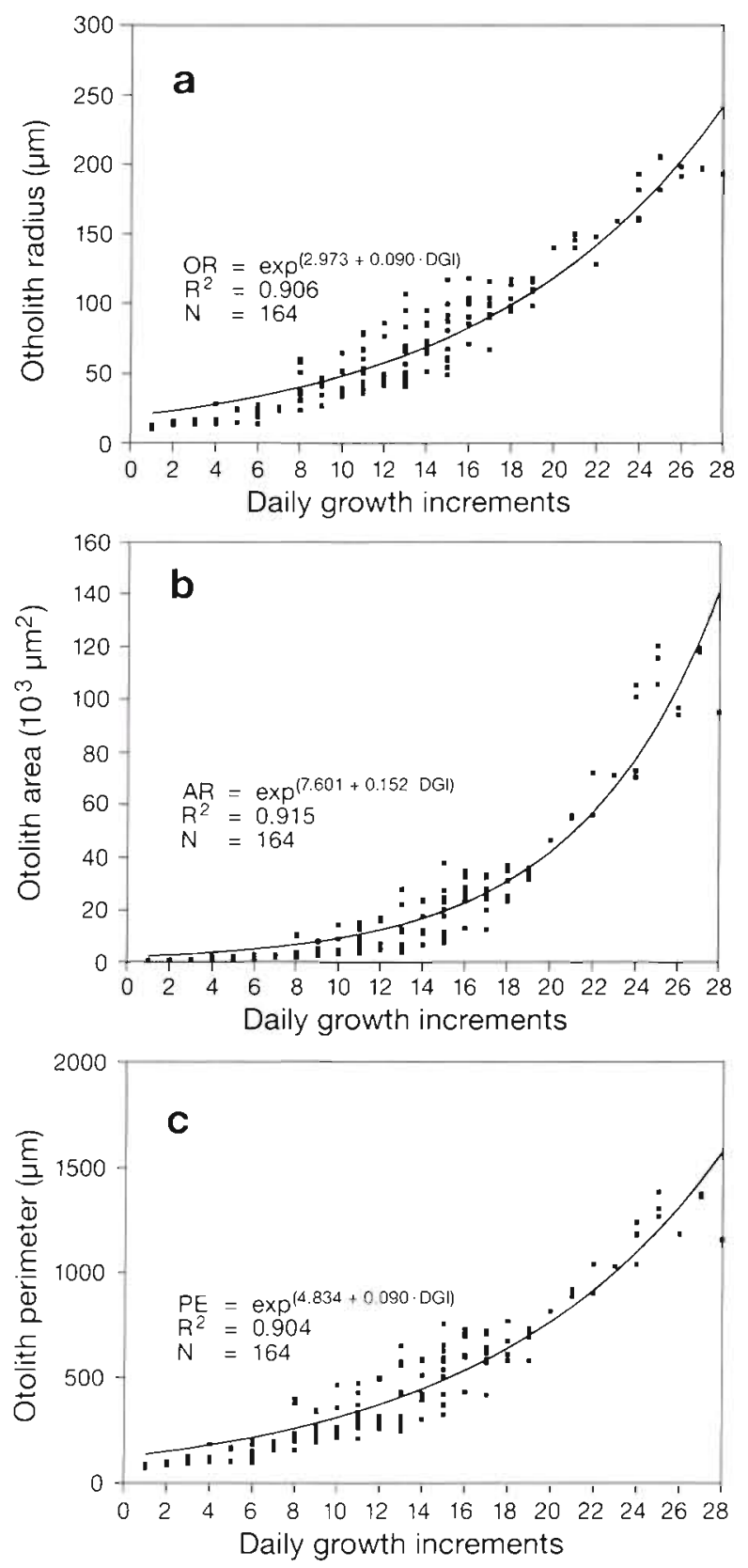

Fig. 7 Osmerus eperlanus. Relationship between number of daily growth increments (DGl) and different otolith measurements. Exponential regressions for (a) DGI versus otolith radius (OR), (b) DGI versus otolith area (AR), and (c) DGI versus otolith perimeter (PE) 


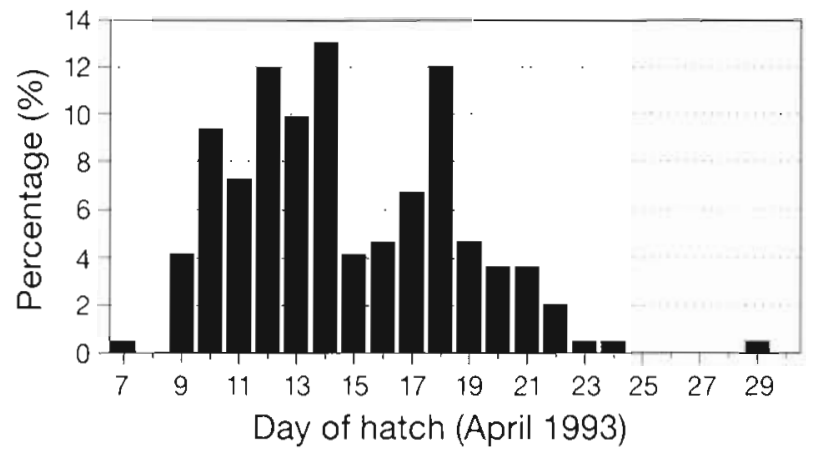

Fig. 8. Osmerus eperlanus. Hatching date distribution of smelt larvae sampled in April-May 1993 back-calculated from 219 larvae

The hatching date distribution given in Fig. 8 was evaluated for possible temporal variations in otolith growth taking into consideration the fluctuations in increment size of sagittae. Three age groups were considered: smelt larvae which hatched between 7 to 15 April, between 16 to 19 April, and between 20 to 29 April. The mean cumulative widths of the daily growth increments for 3 hatching groups of smelt larvae in relation to back-calculated age of larvae are shown in Fig. 9. There were no significant differences between the slopes of the fitted curves (ANCOVA, $F=0.541, \mathrm{p}>0.05$ ). However, the curvilinearity of the growth trajectories in Fig. 9 suggests that the mean cumulative widths of the otolith increments at age were best fitted with a 1-cycle Gompertz function (Zweifel \& Lasker 1976). The final model is summarized in the following equation:

$$
L=L_{0} \exp \left\{\frac{G}{\alpha}[1-\exp (\alpha T)]\right\}
$$

where $L$ is the mean width of cumulative daily growth increments, $L_{0}$ is the width of the increment at hatching $(0.453 \mu \mathrm{m}, \mathrm{SE}=0.180), G$ is the otolith growth rate at hatching $\left(0.420 \mathrm{~d}^{-1}, \mathrm{SE}=0.049\right)$, $\alpha$ is the rate of exponential decay of $G\left(0.062 \mathrm{~d}^{-1}, \mathrm{SE}=0.005\right)$ and $T$ is the back-calculated age from the hatched date (adjusted $\left.\mathrm{R}^{2}=0.996, \mathrm{n}=63, \mathrm{p}<0.001\right)$.

\section{Dissolved oxygen and otolith growth}

Water temperature and salinity were relatively stable during the sampling period with mean values of $17.8^{\circ} \mathrm{C}\left(\mathrm{SD}=0.59^{\circ} \mathrm{C}\right)$ and $0.39 \%$ ( $\mathrm{SD}=0.03 \%$ ), respectively. In contrast, higher fluctuations of dissolved oxygen $\left(\right.$ mean $=5.37 \mathrm{mg} \mathrm{l}^{-1}, \mathrm{SD}=2.00 \mathrm{mg}$ $1^{-1}$ ) with minimum values of $<3.5 \mathrm{mg} \mathrm{l}^{-1}$ were registered during $3 \mathrm{~d}$ in May 1993. Similar to the DLI calculations (Eq. 3), the difference in the width between

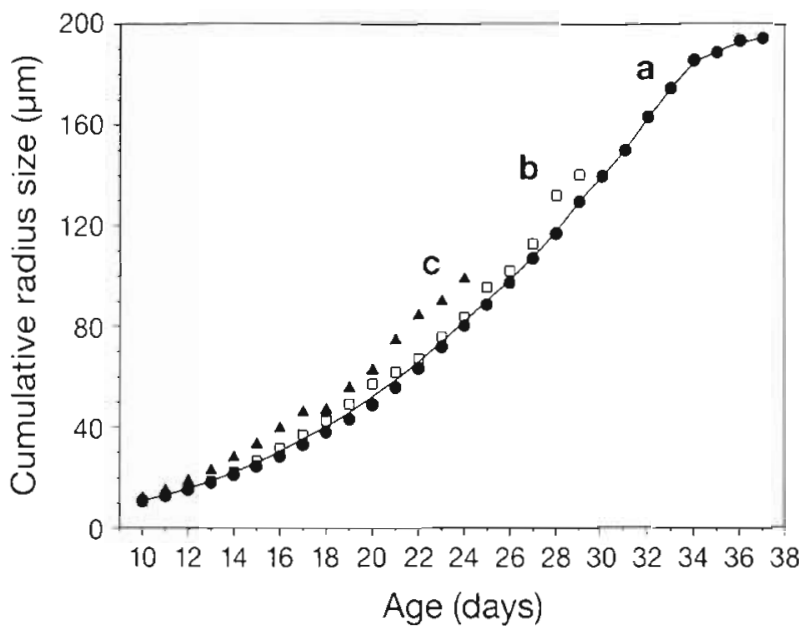

Fig. 9. Osmerus eperlanus. Relationship between the backcalculated age and the cumulative mean size (width of the increments) measured along the otolith radius of 219 smelt larvae for (a) larvae hatched between 7 and 15 April, (b) larvae hatched between 16 and 19 April, and (c) larvae hatched between 20 and 29 April. The curve represents the fit to the Gompertz growth model

the last 2 growth increments for each sampling date was used to estimate recent growth in 158 otoliths. Likewise, recent growth was back-calculated for the day prior to each sampling date using the difference in the width of the next 2 growth increments. Maximum and minimum daily oxygen concentrations were averaged and related to 22 daily average recent growth estimates for the period 26 April to 17 May 1993. A significant fit was derived for this relationship $\left(\mathrm{R}^{2}=0.766, \mathrm{p}<0.001\right)$ and a threshold effect was observed in otolith growth for oxygen concentrations $<4.5 \mathrm{mg} \mathrm{l}^{-1}$ (Fig. 10).

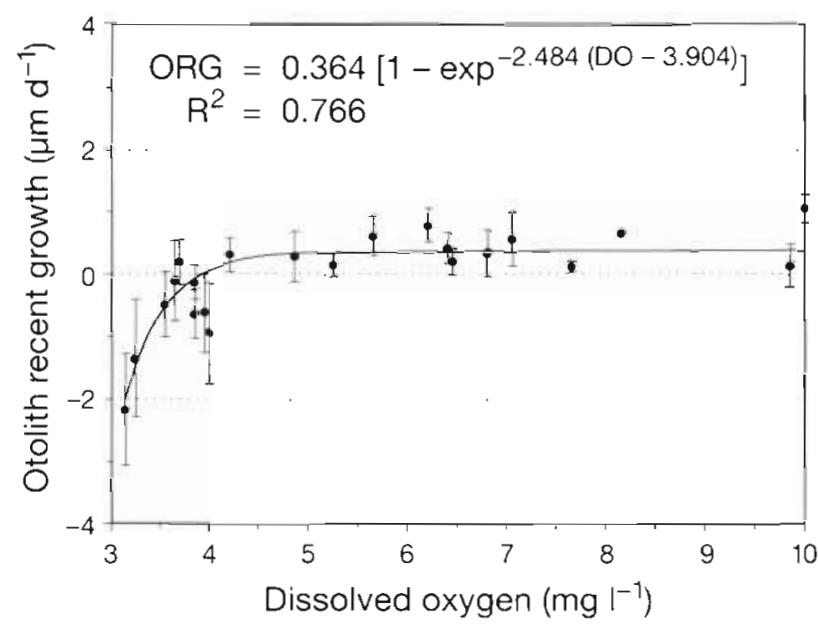

Fig. 10. Osmerus eperlanus. Relationship of otolith recent growth (ORG) and dissolved oxygen (DO), showing curve and fitted equation. Bars represent standard error 


\section{DISCUSSION}

Marginal increment analysis is often used as a standard technique to follow the annual increment formation in adult fish. Given the difficulties in discerning the increments near the larval otolith margin, determination of the completion of the last (marginal) increment is not always conclusive (Geffen 1992). This study confirms the daily nature of otolith growth increments in European smelt larvae using the marginal increment technique described for fish larvae by Ré (1984). Smelt otoliths allow the use of this technique due to their clear microstructure and relatively wide increments (ca $4 \mu \mathrm{m}$ ), at least in fish larvae larger than $8 \mathrm{~mm}$. The marginal increment technique was used succesfully allowing the calculation of a meaningful index of completion (c) attributed to the positive relationship between increasing average otolith increments and age of smelt larvae. However, the method may produce confusing resuits leading to high variations in otolith growth, if highly variable environmental conditions occur. Morales-Nin (1992) pointed out that this method is applicable to fish larvae which remain in the same area and do not migrate vertically during the day. These conditions were met at the station sampled in this study. Firstly, the sampling sites are located in shallow marginal areas of the lower Elbe estuary, where current velocities are about $10 \%$ lower than those abserved in the main stream (Thiel et al. 1994), leading to lower drift effects of smelt larvae in the marginal areas. Sepúlveda et al. (1993) found that smelt larvae achieve maximal retention in the study area, whereby maximal larval densities of 600 ind. $\mathrm{m}^{-3}$ were found for the same sampling period. Möller (1988) suggested that the main spawning grounds for the species are probably located in this area of the southern shoreline of the lower Elbe River. Secondly, at these stations the mean depth is $2.4 \mathrm{~m}$, therefore smelt larvae do not make significant vertical migrations through the water column.

Earlier studies showed the importance of zooplankton, particularly the larval stages of the copepod Eurytemora affinis and cladocerans, as feeding resources in this area (Ladiges 1935, Fiedler 1991). High growth rate estimates $\left(0.556 \mathrm{~mm} \mathrm{~d}^{-1}\right)$ in waters with a mean temperature of $17.8^{\circ} \mathrm{C}$ were found. No information was found in the literature on the growth of European smelt larvae that would permit comparisons of these results. Similar daily length increments for larvae between 5 and $20 \mathrm{~mm}$ can only be inferred from Ehrenbaum's (1894) investigations. The growth rate of rainbow smelt Osmerus mordax larvae from Lake Michigan during the period May-June 1979 fluctuated between 0.30 and $0.37 \mathrm{~mm} \mathrm{~d}^{-1}$ (Tin \& Jude 1983).
Hatching date distribution analysis is considered as one of the most promising tools for the study of recruitment processes (Campana \& Jones 1992). This method can only be used when the samples are collected over a long period of time, allowing a better approximation of the real dates of production of the newly hatched larvae. In this study, nearly the entire hatching duration in 1993 was covered.

The back-calculated hatching date distribution of smelt larvae collected in April-May 1993 showed 2 peaks within the main hatching season. This bimodality is reflected in the breadth of the length-frequency data. No significant or anomalous changes in the environmental factors were found to explain this phenomenon. Hatching duration was estimated to be approximately $16 \mathrm{~d}$ for 1993. Lillelund (1961) reported a mean hatching span averaging $14 \mathrm{~d}$ for the years 1954 to 1969. In field experiments done by Borchardt (1986), smelt eggs hatched at $12^{\circ} \mathrm{C}$ after approximately $17 \mathrm{~d}$. Considering these determinations, one can estimate that for 1993, smelt spawned between 22 March and 7 April with a peak in spawning effort on 29 March.

Otolith growth rates estimated for 3 previously defined hatching groups were not statistically different during the studied period. The Gompertz growth model fitted for larval age versus the cumulative widths along otolith radius, and the relationships between daily growth increments and 3 otolith measurements (Fig. 7), give evidence for an inflexion point for larvae over $33 \mathrm{~d}$ old. Strong seasonal oscillations of the linear growth of the smelt population of the Loire estuary, excluding fish larvae, were found by Lardeaux (1986b).

A number of fish species, particularly anadromous salmonids, but also marine species, show immediate signs of disturbed physiology and metabolism at low oxygen concentrations (Davenport \& Sayer 1993). A dissolved oxygen level of ca $3 \mathrm{mg} \mathrm{l}^{-1}$ was found to be critical $\left(\mathrm{LD}_{50}\right)$ for herring larvae (De Silva \& Tytler 1973). In the Elbe estuary adult smelt and flounder show escape responses at oxygen concentrations $<3 \mathrm{mg} \mathrm{l}^{-1}$ (Thiel et al. 1994). Smelt larvae are not able to swim out of hypoxic conditions, and were maintained in the marginal areas (Sepúlveda et al. 1993). Low oxygen concentrations ( $<4.5 \mathrm{mg} \mathrm{l}^{-1}$ ) caused more variability, as well as decreased values, in recent otolith growth of smelt. Similar effects have also been described for daily increment in otoliths of common dab Limanda limanda L. from the Kiel Bight under oxygen deficiency conditions (Karakiri \& Temming 1988). According to Brett (1979) there is a critical concentration below which growth rate declines at low oxygen levels. For temperate region species, i.e. largemouth bass, carp and coho salmon, he found this value to be about $5 \mathrm{mg} \mathrm{l}^{-1}$ 
Image analysis appears to be a reliable method for semi automatic counting of daily growth increments and otolith measurements. Measurements of areas and perimeters are very simple to perform around the otoliths with the use of auto- and manual tracing functions. Such methods avoid subjective decision-making as to which axis should be measured (Michaud et al. 1988) and in some cases, where one should define the centre for each primardium. In addition, they are more reliable and accurate. All power regressions on different measurements showed a fairly good fit to larval length, whereas area showed a better fit and lower standard error with respect to the other measurements (Fig. 6). Moreover, otolith areas are 2-dimensional variables which can be more closely related to somatic growth and could give more realistic explanations for growth effects in some fish species. This was discussed, for example by Secor \& Dean (1992) based on otolith diameter to standard length relationships, whereby relatively larger otoliths were found in slower-growing larvae. Area measures will be considered in future investigations to test the accuracy of different growth back-calculation methods and their relationship to somatic growth in smelt.

Acknowledgements. I am grateful to R. Kafemann, captain of the RV 'Ratibor' The technical assistance of S. Stäcker and $\mathrm{S}$. Sir is greatly appreciated. P. Ré introduced me to some of the concepts and techniques discussed in this paper, and to him I express my gratitude. A del Norte-Campos and R. Thiel provided helpful comments on the manuscript. I thank T. Gaumert, Arbeitsgemeinschaft für die Reinhaltung der Elbe (ARGE ELBE), for providing unpublished oxygen concentration data. This manuscript benefited from reviews by 3 anonymous reviewers. This research was financially supported by a grant of the Deutsche Forschungsgemeinschaft (DFG) and a doctoral scholarship from the German Academic Exchange Service (DAAD).

\section{LITERATURE CITED}

Borchardt, D. (1986). Untersuchungen über die Stinte der 0 -Gruppe in Abhängigkeit von den Umweltbedingungen in der Elbe 1985. M.Sc. thesis, Universität Hamburg, p. 103

Brett, J. R. (1979). Environmental factors and growth. In: Hoar, W. S., Randall, D. J., Brett, J. R. (eds.) Fish physiology, Vol. 8. Academic Press, London, p. 599-675

Brothers, E. B., McFarland, W. N. (1981). Correlations between otolith microstructure, growth, and life history transitions in newly recruited French grunts (Haemulon flavolineatum). Rapp. P.-v. Réun. Cons. perm. int. Explor Mer 178: 369-374

Campana, S. E. (1992). Measurement and interpretation of the microstructure of fish otoliths. In: Stevenson, D. K., Campana, S. E. (eds.) Otolith microstructure examination and analysis. Can. Spec. Publ. Fish. Aquat. Sci. 117: 59-71

Campana, S. E., Jones, C. (1992). Analysis of otolith microstructure data. In: Stevenson, D. K., Campana, S. E. (eds.) Otolith microstructure examination and analysis. Can. Spec. Publ. Fish. Aquat. Sci. 117: 73-100
Davenport, J., Sayer, M. D. J. (1993). Physiological determinants of distribution in fish. J. Fish Biol. 43 (Suppl. A): $121-145$

De Silva, C. D., Tytler, P. (1973). The influence of reduced environmental axygen on the metabolism and survival of herring and plaice larvae. Neth. J. Sea Res. 7: 345-362

Ehrenbaum, E. (1894). Beiträge zur Naturgeschichte einiger Elbfische. Wiss. Meeresunters. (Abt. Helgoland) N.F. 1. $35-82$

Fiedler, M. (1991). Die Bedeutung von Makrozoobenthos und Zooplankton der Unterelbe als Fischnahrung. Ber Inst. Meereskde Kiel 204: 226

Garnås, E. (1982). Growth of different year classes of smelt Osmerus eperlanus L., in Lake Tyrifjorden, Norway. Fauna norv. (Ser. A) 3: 1-6

Geffen, A. J. (1992). Validation of otolith increment deposition rate. In: Stevenson, D. K., Campana, S. E. (eds.) Otolith microstructure examination and analysis. Can. Spec. Publ. Fish. Aquat. Sci. 117: 101-113

Houde, D. E., Scheckter, R. C. (1981). Growth rates, rations and cohort consumption of marine fish larvae in relation to prey concentrations. Rapp. P.-v. Réun. Cons. perm. int. Explor. Mer 178: 441-453

Karakiri, M., Berghahn, R, van der Veer, H. W. (1991). Variations in seltlement and growth of 0 -group plaice (Pleuronectes platessa L.) in the Dutch Wadden Sea as determined by otoliths microstructure analysis. Neth. J. Sea Res. 27: 345-351

Karakiri, M., Temming. A. (1988). Effects of oxygen deficiency in the Kiel Bight on the daily increment formation in otoliths of common dab, Limanda limanda $\mathrm{L}$. Verh. $\mathrm{dt}$. zool. Ges. 81: 323 (in German)

Karakiri, M., von Westernhagen, H. (1989). Daily growth patterns in otoliths of larval and juvenle plaice (Pleuronectes platessa): influence of temperature, salinity and light conditions. Rapp. P.-v. Réun. Cons perm. int. Explor. Mer 191: 376-382

Ladiges, W. (1935). Über die Bedeutung der Copepoden als Fischnahrung im Unterelbegebiet. Z. Fisch. 33: 1-84

Lardeaux, F. (1986a). Biologie, écologie et dynamique de population de l'eperlan (Osmerus eperlanus L.) (Poisson. Clupéiforme, Osméridél dans l'estuaire de la Loire (France). Thèse de Doctorat, Universite de Bretagne Occidentale, p. 614

Lardeaux, F. (1986b). Éléments de dynamique de population de l'eperlan (Osmerus eperlanus) dans l'estuaire de la Loire. J. Rech. océanogr. 11: 25-28

Lillelund, K. (1961). Untersuchungen über die Biologie und Populationsdynamik des Stintes Osmerus eperlanus (Linnaeus, 1758) der Elbe. Arch. FischWiss. 12: 1-128

Michaud, M., Dutil, D. D., Dodson, J. J. (1988). Determination of the age of young American eels, Anguilla anguilla, in freshwater, based on otolith surface area and microstructure. J. Fish Biol. 32: 179-189

Moksness, E. (1992). Validation of daily increments in the otolith microstructure of Norwegian spring-spawning herring (Clupea harengus L.) ICES J. mar. Sci. 49: 231-235

Möller, H. (1988). Fischbestände und Fischkrankheiten in der Unterelbe 1984-1986. Möller, Kiel, p. 344

Möller, H., Scholz, U. (1991). Avoidance of oxygen-poor zones by fish in the Elbe River. J. appl. lchthyol. 7: 176-182

Morales-Nin, B. (1992). Determination of growth in bony fishes from otolith microstructure. FAO Fish. tech. Pap. 322. FAO, Rome, p. 51

Ré, P. (1983). Daily growth increments in the sagitta of pilchard larvae Sardina pilchardus (Walbaum, 1792) (Pisces: Clupeidae). Cybium 7: 9-15 
Ré, P. (1984). Evidence of daily and hourly growth in pilchard larvae based on otolith growth increments, Sardina pilchardus (Walbaum, 1792). Cybium 8: 33-38

Ré, P., Gonçalves, E. (1993). Growth of sprat (Sprattus sprattus) larvae in the German Bight (North Sea) as inferred by otolith microstructure. Mar. Ecol. Prog. Ser. 96: 139-145

Reincke, H., Lischke, P., Schindler, J. (1992). Vorstellung der Ergebnisse der Arbeitsgruppe 'Meß- und Untersuchungsprogramme' der Internationalen Kommission zum Schutz der Elbe. Veröffentlichungen des 4. Magdeburger Gewässerschutzseminars zur Situation der Elbe. GKSS Institut für Gewässerforschung, Magdeburg, p. 275-282

Rice, J. A., Crowder, L. B., Holey, M. E. (1987). Exploration of mechanisms regulating larval survival in Lake Michigan bloater: a recruitment analysis based on characteristics of individual larvae. Trans. Am. Fish. Soc. 116: 703-718

Secor, D. H., Dean, J. M. (1992). Comparison of otolith-based back-calculation methods to determine individual growth histories of larval striped bass, Morone saxatilis. Can. J. Fish. Aquat. Sci. 47: 2219-2227

Sepúlveda, A., Thiel, R., Nellen, W. (1993). Distribution patterns and production of early life stages of European

This article was submitted to the editor smelt, Osmerus eperlanus L., from the Elbe River. Comm. Meet. int. Coun. Explor. Sea C.M.-ICES/M:52, p. 20

Tanaka, K., Mugiya, Y., Yamada, J. (1981). Effects of photoperiod and feeding on daily growth patterns in otoliths of juvenile Tilapia nilotica. Fish. Bull. U.S. 79: 459-466

Thiel, R., Sepúlveda, A., Kafemann, R., Nellen, W. (1994). Environmental factors as forces structuring the fish community of the Elbe estuary. J. Fish Biol. (in press)

Timola, O. (1977). Scanning electron microscope studies on the growth patterns of smelt, Osmerus eperlanus (L.) otoliths. Aquilo Ser Zool. 17: 57-60

Tin, H. T., Jude, D. J. (1983). Distribution and growth of larval rainbow smelt in eastern Lake Michigan, 1978-1981. Trans. Am. Fish. Soc. 112: 517-524

Tsukamoto, K., Kuwada, H., Hirokawa, J., Oya, M., Sekiya, S. Fujimoto, H., Imaizumi, K. (1989). Size dependent mortality of red sea bream, Pagrus major, juveniles released with fluorescent otolith tags in News Bay, Japan. J. Fish Biol. 35 (Suppl. A): 59-69

Zweifel, J. R., Lasker, R. (1976). Prehatch and posthatch growth of fishes - a general model. Fish. Bull. U.S. 74: $609-621$

Manuscript first received: November 24, 1993

Revised version accepted: March 16, 1994 